\title{
Sistem Pakar Untuk Mendiagnosa Penyakit Menular Seksual (HIV/AIDS) Dengan Menggunakan Metode Case Based Reasoning (CBR)
}

\author{
Trinanda Syahputra, Jufri Halim, Ishak \\ STMIK Triguna Dharma
}

\begin{tabular}{|c|c|}
\hline Article Info & ABSTRACT \\
\hline Article history: & Penyakit menular seksual (PMS) adalah infeksi yang menular lewat \\
\hline Received Sep $17^{\text {th }}, 2018$ & hubungan seksual,baik dengan pasangan yang sudah tertular, maupun \\
\hline Revised Okt 22 $2^{\text {th }}, 2018$ & mereka yang sering berganti - ganti pasangan. Pada jaman sekarang \\
\hline Accepted Des $20^{\text {th }}, 2019$ & banyak sekali jenis penyakit yang bisa menyebabkan kelumpuhan \\
\hline & beberapa pembahasan yang diangkat yaitu: pengertian, penyebab, \\
\hline Keyword: & gejala dan solusi pencegahan penyakit menular seksual(HIV/AIDS). \\
\hline Sistem Pakar & Sistem pakar dirancang dengan metode case based reasoning (CBR). \\
\hline Penyakit Menular Seksual & Metode sitem pakar merupakan salah satu metode pemecahan \\
\hline Case Based Reasonıng & $\begin{array}{l}\text { masalah yang dalam mencari solusi dari suatu yang baru, sistem akan } \\
\text { melakukan pencarian terhadap solusi dari kasus lama yang memiliki } \\
\text { permasalahan yang sama dan sudah pernah terjadi sebelumnya. }\end{array}$ \\
\hline & $\begin{array}{l}\text { Hasil solusi dari sistem pakar ini memudahkan para penderita } \\
\text { penyakit menular seksual (HIV/AIDS) untuk mencegah dan } \\
\text { mengetahui penykit menular seksual dari gejala - gejala serta solusi } \\
\text { yang sudah ada. }\end{array}$ \\
\hline
\end{tabular}

\section{PENDAHULUAN}

Penyakit merupakan penyebab gangguan kesehatan pada tubuh manusia dan semua itu tidak asing lagi bagi masyarakat, suatu gejala penyakit merupakan indikasi dari suatu penyakit yang diderita oleh semua manusia. Setiap orang wajib menjaga kesehatan, tetapi pada kenyataannya banyak sekali manusia lupa bahkan meremehkan gejala penyakit yang diderita, maka dengan adanya kemajuan teknologi saat ini suatu penyakit akan terdeteksi dengan lebih cepat melalui gejala tersebut. Pada jaman sekarang banyak sekali jenis penyakit yang bisa menyebabkan kelumpuhan dan kematian, seperti penyakit menular seksual pada manusia.

Penyakit Menular Seksual (PMS) adalah infeksi yang menular lewat hubungan seksual, baik dengan pasangan yang sudah tertular, maupun mereka yang sering berganti-ganti pasangan. Menurut WHO (World Health Organization) No 110 August 2011, 499 juta infeksi baru dapat menimbulkan penyakit menular seksual (Sifilis, Gonorea, Klamidia dan HIV) terjadi setiap tahun di seluruh dunia pada orang dewasa berusia 15-49 tahun. Resistensi (kekurangan) obat, terutama untuk Gonorea. PMS dapat meningkatkan risiko penyakit HIV tiga kali lipat atau lebih. Selain itu pencegahan terhadap PMS juga terkendala oleh tidak adanya dokter spesialis penyakit menular seksual di beberapa daerah di Indonesia.

Penyebaran dokter spesialis yang belum merata di wilayah Indonesia menyebabkan pasien mengalami kesulitan bila ingin berkonsultasi ke dokter spesialis. Untuk itu perlu dibangun suatu sistem yang terkomputerisasi. Untuk dapat membantu para medis dan mendiagnosa penyakit dengan cara melakukan dialog interaktif mengenai gejala - gejala penyakit yang diderita oleh pasien tanpa kehadiran seorang pakar. Sistem pakar adalah salah satu solusi yang dapat membantu para dokter. Sistem pakar yang dibangun ini bukan untuk menggantikan fungsi dokter, akan tetapi hanya digunakan sebagai pelengkap dan alat bantu yang masih terbatas, karena program diagnosis PMS ini hanya bertindak sebagai penasehat atau konsultatif dan tidak seperti halnya seorang dokter yang dapat mendiagnosis penyakit dengan suatu aksi atau gerakan. Adapun metode yang digunakan yaitu Caseb Base Reasoning (CBR). Metode ini digunakan karena dapat 
digunakan untuk mendiagnosa penyakit dengan membandingkan pada basis kasus yang pernah terjadi sebelumnya. Dan metode ini cukup akurat dalam mendiagnosa suatu penyakit..

\section{LANDASAN TEORI}

\subsection{Sistem Pakar}

Sistem pakar adalah sistem berbasis komputer yang menggunakan pengetahuan, fakta dan teknik penalaran dalam memecahkan masalah yang biasanya hanya dapat dipecahkan oleh seorang pakar dalam bidang tersebut (Nuzla Abidin, 2013 : 2).

Sistem pakar merupakan cabang dari Artificial Intelligence (AI) yang cukup tua karena sistem ini mulai diperkembangkan pada pertengahan 1960. Sistem pakar yang muncul pertama kali adalah General-purpose problem solver (GBS) yang dikembangkan oleh Newel dan Simon. Sampai saat ini sudah banyak sistem pakar yang dibuat, seperti MCYIN untuk diagnosis penyakit, DENDRAL untuk membantu konfigurasi sistem komputer besar, SOPHIE untuk analisis sirkuit elektronik, PROSPECTOR digunakan dibidang geilogi untuk membantu memberikan keputusan bagi seorang meneger dalam stok dan investasi, DELTA dipakai untuk pemeliharahan lokomotif listrik diesel, dan sebagainya.

Istilah sistem pakar barasal dari istilah knowledge-based expert system. Istilah ini muncul karena untuk memecahkan masalah, sistem pakar menggunakan pengetahuan seseorang pakar yang dimasukkan ke dalam komputer. Seseorang yang bukan pakar menggunakan sistem pakar untuk meningkatkan kemampuan pemecahan masalah, sedangkan seorang pakar menggunakan sistem pakar untuk knowledge assistant.

\subsection{Metode Case Based Reasoning (CBR)}

Case Based Reasoning (CBR) merupakan salah satu metode pemecahan masalah yang dalam mencari solusi dari suatu kasus yang baru, sistem akan melakukan pencarian terhadap solusi dari kasus lama yang memiliki permasalahan yang samadan sudah pernah terjadi sebelumnya (Hapnes Toba, 2008 : 135).

Metode CBR dikembangkan oleh Roger Schank dan rekannya di Universitas Yale pada awal tahun 1980. Terdapat dua prinsip dasar pada metode CBR, prinsip pertama adalah setiap permasalahan yang sama akan memiliki solusi yang sama pula. Oleh karena itu, solusi dari permasalahan yang sudah pernah terjadi dapat digunakan kembali untuk memecahkan masalah baru dengan permasalahan yang sama dengan masalah yang lama. Prinsip kedua adalah setiap permasalahan dapat terjadi berulang kali. Oleh karena itu, terdapat kemungkinan bahwa masalah yang akan muncul di masa yang akan datang memiliki kesamaan dengan masalah yang pernah terjadi sebelumnya.

Perhitungan untuk mendapatkan kesamaan antar kasus, sangat penting pada metodeCBR terutama dalam proses retrieval. Efektifitas dari pengukuran kesamaan tergantung dari seberapa banyak kasus yang ditelah, membantu dalam memecahkan masalah pada kasus yang baru. Ada dua pendekatan yang digunakan untuk melakukan perhitungan kesamaan yaitu pendekatan jarak dan struktur indeks. Kedekatan antara dua kasus dalam metode case based reasoningdihitung dengan menggunakan rumus :

$$
\operatorname{sim}(A, B)=\frac{1}{p} \sum_{i=1}^{p} \operatorname{sim}_{i}(a, b)
$$

Dengan:

$\operatorname{Sim}(\mathrm{A}, \mathrm{B}) \quad=$ kemiripan kasus ke-a dan ke-b.

Semakin tinggi nilai yang didapat maka kedekatannya pun akan semakin tinggi. Sebaliknya semakin rendah nilai yang didapat maka, kedekatannya pun semakin rendah. Pada aplikasi ini ditentukan sebuah batas, yaitu jika nilai yang didapat >= nilai yang telah ditentukan maka kasus lama tersebut dapat langsung digunakan kembali untuk menyelesaikan kasus yang baru.

\subsection{Penyakit Menular Seksual}

Penyakit menular seksual atau PMS, atau dikenal dengan istilah infeksi menular seksual (IMS), adalah penyakit atau infeksi yang umumnya ditularkan melalui hubungan seks yang tidak aman. Penyebaran bisa melalui darah, sperma, cairan vagina atau pun cairan tubuh lainnya. Selain itu, penyebaran tanpa hubungan seksual juga bisa terjadi dari seorang ibu kepada bayinya, baik saat mengandung atau melahirkan. Pemakaian jarum suntik secara berulang atau bergantian di antara beberapa orang juga berisiko menularkan infeksi..

Berikut ini adalah beberapa penyakit menular seksual yang umum terjadi.

1. Sifilis atau raja singa adalah penyakit seksual yang disebabkan oleh infeksi bakteri Treponema pallidum.Gejala awal sifilis adalah munculnya lesi atau luka

2. pada alat kelamin atau pada mulut.Luka ini mungkin tidak terasa sakit, tapi sangat mudah untuk menularkan infeksi. Luka atau lesi ini akan bertahan antara 1-2.5 bulan. 
3. Gonore atau kencing nanah adalah penyakit menular seksual yang disebabkan oleh bakteri Neisseria gonorrhoeae. Beberapa penderita penyakit ini tidak menunjukkan gejala apa pun sehingga bisa tidak diketahui sama sekali

4. Chlamydia atau klamidia adalah jenis penyakit seksual umum yang disebabkan oleh bakteri Klamidia trachomatis. Beberapa orang tidak merasakan gejala sama sekali, jadi penularan bisa terjadi tanpa disadari oleh orang yang sudah terinfeksi.

5. Herpes genital adalah penyakit seksual yang disebabkan oleh herpes simpleks virus atau sering disebut HSV. Gejala herpes genital akan muncul beberapa hari setelah terinfeksi HSV. Luka melepuh berwarna kemerahan serta rasa sakit pada wilayah genital menjadi gejala herpes awal yang muncul. Mungkin akan terasa gatal atau sakit saat membuang air kecil.

6. HIV atau human immunodeficiency virus adalah virus yang menyerang sistem kekebalan tubuh.Virus ini dapat tertular melalui hubungan seks yang tidak aman, berbagi alat suntik atau pun jarum, dari ibu kepada bayinya, maupun melalui transfusi darah.

\section{PEMBAHASAN DAN HASIL}

Untuk menyelesaikan permasalahan yang terjadi maka digunakan metode Case Based Reasoning (CBR) untuk dapat mengetahui Penyakit menular seksual pria berdasarkan gejala-gejala yang dialami. Berikut merupakan Penyakit menular seksual pria berdasarkan gejala-gejala yang umum di derita.

Tabel.1 Daftar Penyakit

\begin{tabular}{|c|c|c|}
\hline No & Kode Penyakit & Nama Penyakit \\
\hline 1 & PK001 & Gonorhea \\
\hline 2 & PK002 & Sifilis \\
\hline 3 & PK003 & Herpes \\
\hline 4 & PK004 & AIDS \\
\hline 5 & PK005 & Kutil Kelamin \\
\hline
\end{tabular}

Tabel.2 Gejala Penyakit Menular Seksual Pada Pria

\begin{tabular}{|c|l|l|}
\hline No & Kode & \\
\hline 1 & GP001 & Keluar nanah dari saluran kencing dan rasanya panas seperti terbakar \\
\hline 2 & GP002 & Ujung buah zakar berwarna merah dan membengkak \\
\hline 3 & GP003 & Terasa sakit yang luar biasa saat buang air kecil \\
\hline 4 & GP004 & Air kencing berwarna kuning kehijauan \\
\hline 5 & GP005 & Rasa sakit di bagian anus, alat kelamin dan mulut \\
\hline 6 & GP006 & $\begin{array}{l}\text { Muncul raum pada telapak tangan kaki dan wajah serta bagian tubuh } \\
\text { lainnya. }\end{array}$ \\
\hline 7 & GP007 & $\begin{array}{l}\text { Setelah dua tahun setelah infeksi bakteri merusak sistem saraf otak dan } \\
\text { sistem darah }\end{array}$ \\
\hline 8 & GP 008 & $\begin{array}{l}\text { Terjadinya pembesaran kelenjer limfe inguinal medial unilateral atau } \\
\text { bilateral }\end{array}$ \\
\hline 9 & GP009 & Terjadi pembesaran getah bening \\
\hline No & Kode & Gejala Penyakit \\
\hline 10 & GP010 & Terdapat bentuk luka di atas penis \\
\hline 11 & GP011 & Gejala sistematik (malaise, demam, mialgia, sakit kepala \\
\hline 12 & GP012 & $\begin{array}{l}\text { Muncul bercak kemerahan yang kecil dan diikuti oleh sekumpulan lepuhan } \\
\text { kecil yang terasa nyeri }\end{array}$ \\
\hline 13 & GP013 & Kesulitan berkemih dan ketika berjalan timbul rasa nyeri \\
\hline 14 & GP014 & Pertumbuhan yang jelek \\
\hline 15 & GP015 & Penurunan berat badan \\
\hline 16 & GP016 & Demam yang berlangsung lama dan berulang \\
\hline 17 & GP017 & Diare yang menetap dan berulang \\
\hline
\end{tabular}




\begin{tabular}{|l|l|l|}
\hline 18 & GP018 & Pembengkakan kelenjer liur dan pipi \\
\hline 19 & GP019 & Infeksi jamur yang menetap atau berulang \\
\hline 20 & GP020 & Infeksi bakteri berulang \\
\hline 21 & GP021 & Pembesaran hati dan limpa \\
\hline 22 & GP022 & Kemunduran perkembangan sistem saraf \\
\hline 23 & GP023 & Muncul kutil pada penis \\
\hline 24 & GP024 & Berbau busuk \\
\hline
\end{tabular}

Tabel 4 Tabel Solusi

\begin{tabular}{|c|c|l|}
\hline No & Kode Solusi & \multicolumn{1}{c|}{ Solusi Penyakit } \\
\hline 1 & S01 & $\begin{array}{l}\text { Sangat penting untuk minum obat antibiotik sesuai dosis dan jangka waktu } \\
\text { yang dianjurkan agar infeksi benar-benar lenyap. Jika tidak ditangani dengan } \\
\text { baik, gonore atau kencing nanah bisa menyebabkan kemandulan. }\end{array}$ \\
\hline 2 & S02 & $\begin{array}{l}\text { Antibiotik seperti suntikan penisilin dapat digunakan untuk mengobati } \\
\text { sifilis. Hindari hubungan seksual sebelum memastikan infeksi sifilis benar- } \\
\text { benar hilang. }\end{array}$ \\
\hline 3 & S03 & $\begin{array}{l}\text { Obat-obatan antiherpes yang paling sering digunakan adalah:Asiklovir, } \\
\text { Famsiklovir danValasiklovir }\end{array}$ \\
\hline 4 & S04 & $\begin{array}{l}\text { Antiretroviral (ARV) adalah beberapa obat yang digunakan untuk mengobati } \\
\text { infeksi HIV. Obat-obatan ini tidak membunuh virus, tapi memperlambat } \\
\text { pertumbuhan virus. }\end{array}$ \\
\hline 5 & S05 & $\begin{array}{l}\text { Pengobatan topikal dilakukan dengan cara mengoleskan salep, krim, atau } \\
\text { cairan yang mengandung zat tertentu pada bagian yang terinfeksi dengan } \\
\text { Asam trikloroasetat, PodophyllotoxinatauImiquimod }\end{array}$ \\
\hline
\end{tabular}

Misalnya kasus baru berisi data usia pasien 30 tahun dan gejala yang dialami yaitu GP007, GP010, GP011, GP012, GP013, GP015. Maka untuk kasus baru ini akan dihitung kemiripannya dengan kasus-kasus yang ada dengan gejala pada basis kasus dengan menggunakan persamaan sebagai berikut:

1. Similarity dengan Kasus K001

$$
\begin{aligned}
\operatorname{Sim}(A, B) & =\frac{0+0+0+0+0+1}{6} \\
& =\frac{1}{6} \\
& =0,167 \%
\end{aligned}
$$

2. Similarity dengan Kasus K002

$$
\begin{aligned}
\operatorname{Sim}(A, B) & =\frac{0+0+0+0+0+0}{6} \\
& =\frac{0}{6} \\
=0 \% &
\end{aligned}
$$

3. Similarity dengan Kasus K003

$$
\begin{aligned}
\operatorname{Sim}(A, B) & =\frac{0+1+0+1+0+0}{6} \\
& =\frac{2}{6} \\
= & 0,333=33,3 \%
\end{aligned}
$$

4. Similarity dengan Kasus K004

$$
\begin{aligned}
\operatorname{Sim}(A, B) & =\frac{1+0+1+0+0+1}{6} \\
& =\frac{3}{6}
\end{aligned}
$$




$$
=0,5=50 \%
$$

5. Similarity dengan Kasus K005

$$
\begin{aligned}
\operatorname{Sim}(A, B) & =\frac{0+1+0+0+0+0}{6} \\
& =\frac{1}{6} \\
& =0,167=16,7 \%
\end{aligned}
$$

6. Similarity dengan Kasus K006

$$
\begin{aligned}
\operatorname{Sim}(A, B) & =\frac{0+0+0+0+1+0}{6} \\
& =\frac{1}{6} \\
& =0,167=16,7 \%
\end{aligned}
$$

7. Similarity dengan Kasus K007

$$
\begin{aligned}
\operatorname{Sim}(A, B) & =\frac{0+0+0+0+0+1}{6} \\
& =\frac{1}{6} \\
& =0,167=16,7 \%
\end{aligned}
$$

8. Similarity dengan Kasus K008

$$
\begin{aligned}
\operatorname{Sim}(A, B) & =\frac{1+1+1+1+0+0}{6} \\
& =\frac{4}{6} \\
& =0,667=66,7 \%
\end{aligned}
$$

9. Similarity dengan Kasus K009

$$
\begin{aligned}
\operatorname{Sim}(A, B) & =\frac{0+0+0+0+0+0}{6} \\
& =\frac{0}{6} \\
= & 0 \%
\end{aligned}
$$

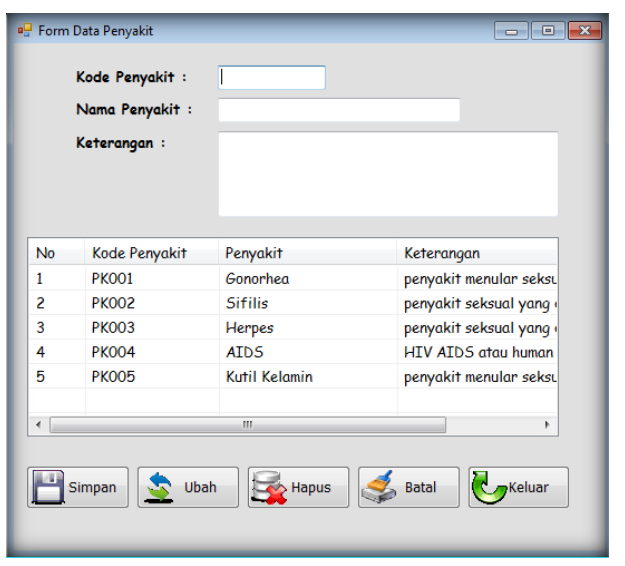

Gambar 1 Form Input Data Penyakit

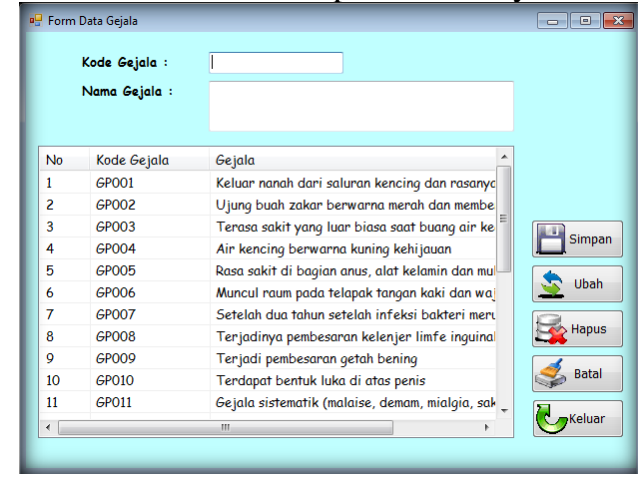

Gambar 2 Form Input Data Gejala 


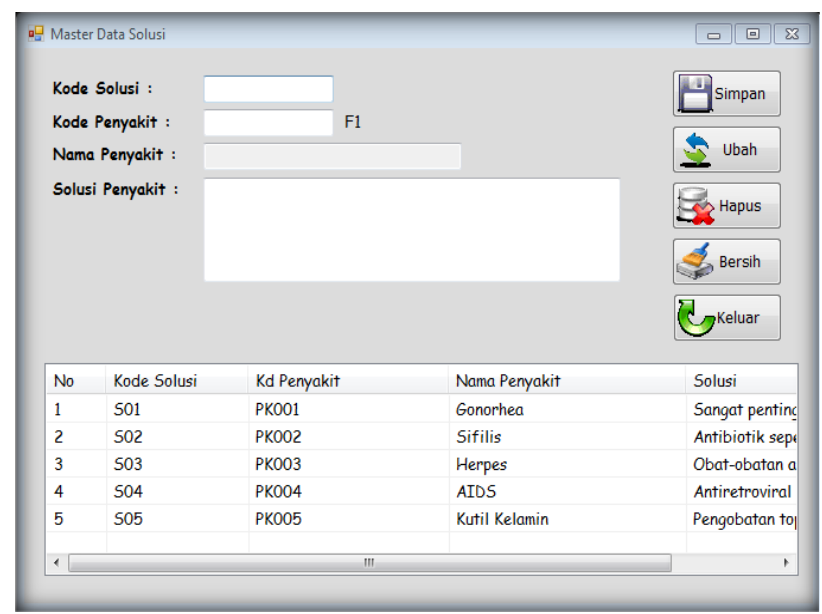

Gambar 3 Input Data Solusi

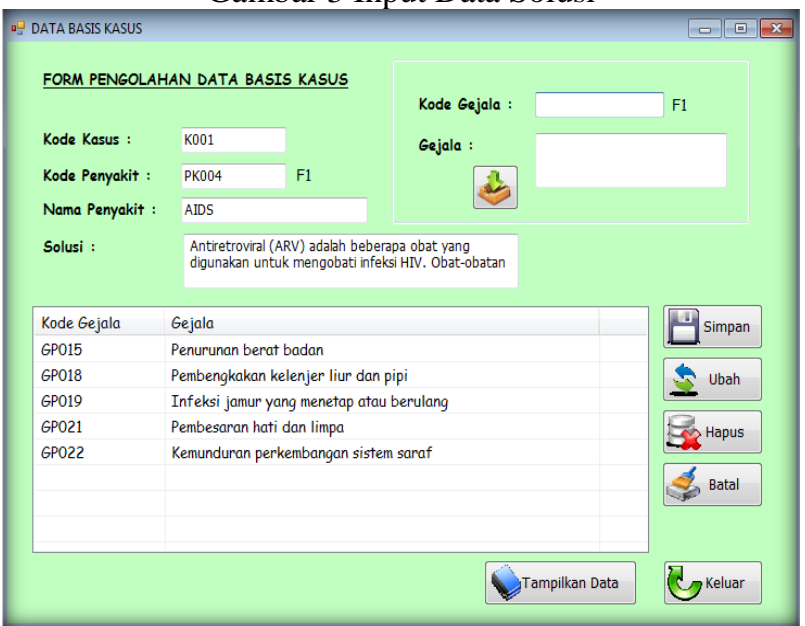

Gambar 4 Basis Kasus

\section{FORM KONSULTASI GEJALA PENYAKIT}

\begin{tabular}{|c|c|c|c|c|}
\hline No & Kode Gejala & \multicolumn{2}{|l|}{ Gejala } & \\
\hline$\square 3$ & GP003 & \multicolumn{2}{|l|}{ Terasa sakit yang luar biasa saat buang air kecil } & \\
\hline$\square 4$ & GP004 & \multicolumn{2}{|l|}{ Air kencing berwarna kuning kehijauan } & \\
\hline$\square 5$ & GP005 & \multicolumn{3}{|l|}{ Rasa sakit di bagian anus, alat kelamin dan mulut } \\
\hline$\square 6$ & GP006 & \multicolumn{3}{|c|}{ Muncul raum pada telapak tangan kaki dan wajah serta bagian ... } \\
\hline V 7 & GP007 & \multicolumn{2}{|c|}{ Setelah dua tahun setelah infeksi bakteri merusak sistem sara... } & \\
\hline$\square 8$ & GP008 & \multicolumn{2}{|c|}{ Terjadinya pembesaran kelenjer limfe inguinal medial unilater... } & \\
\hline$\square 9$ & GPOO9 & \multicolumn{3}{|l|}{ Terjadi pembesaran getah bening } \\
\hline V 10 & GP010 & \multicolumn{3}{|l|}{ Terdapat bentuk luka di atas penis } \\
\hline ( $\nabla 11$ & GP011 & \multicolumn{3}{|c|}{ Gejala sistematik (malaise, demam, mialgia, sakit kepala) } \\
\hline$\nabla 12$ & GP012 & \multicolumn{2}{|c|}{ Muncul bercak kemerahan yang kecil dan diikuti oleh sekumpul... } & \\
\hline$\nabla 13$ & GP013 & \multicolumn{3}{|c|}{ Kesulitan berkemih dan ketika berjalan timbul rasa nyeri } \\
\hline \multicolumn{4}{|c|}{ Konsultasi Halaman 1} & \\
\hline & & (A) Kembali & (C) Lanjut & \\
\hline
\end{tabular}

Gambar 5 Form Konsultasi 


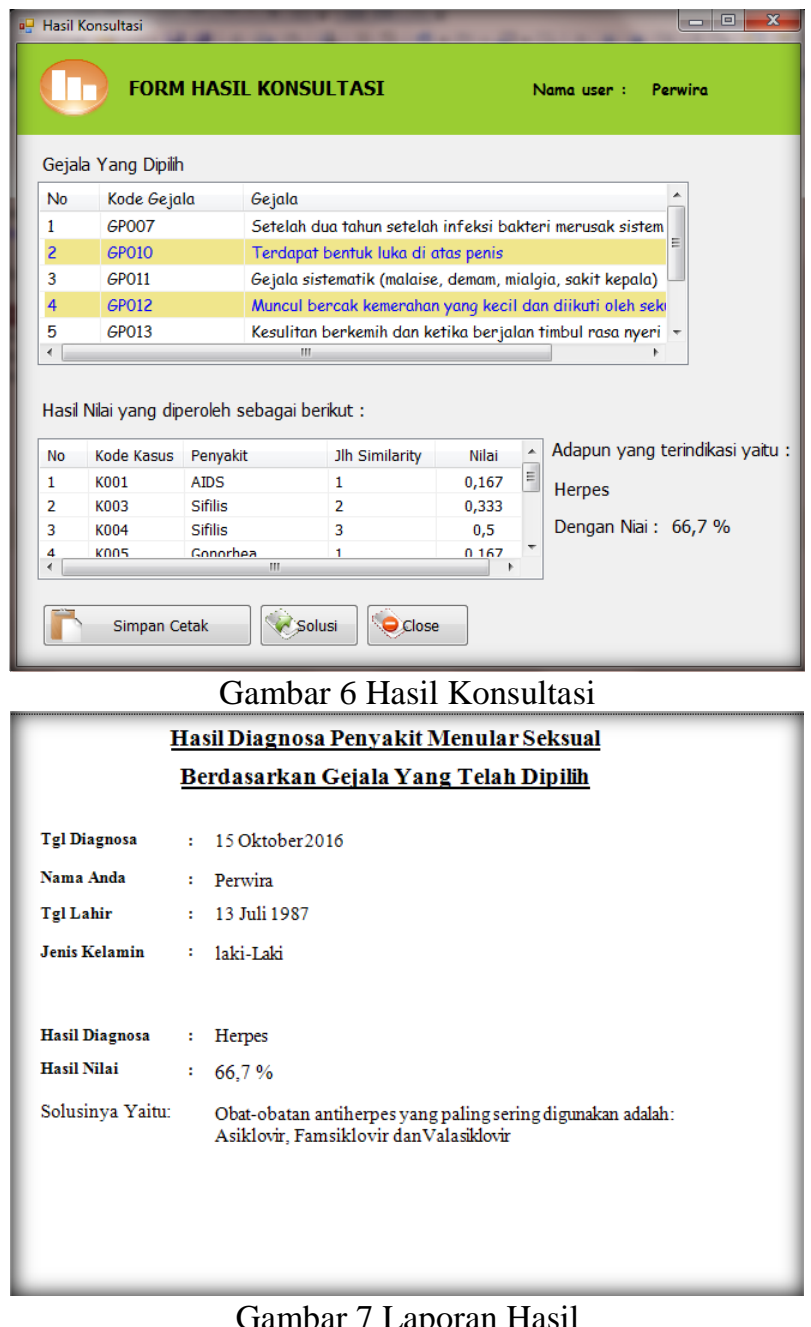

4. KESIMPULAN

Gambar 7 Laporan Hasil

Berdasarkan pembahasan dan evaluasi dari bab terdahulu, maka dapat ditarik kesimpulan sebagai berikut:

1. Langkah-langkah untuk menerapkan metode Case Based Reasoning (CBR) dalam mendiagnosa jenis penyakit menular seksual yaitu dengan memasukkan perhitungan-perhitungan metode CBR ke dalam sistem pakar sehingga dapat memberikan solusi yang tepat terhadap penyakit yang diderita.

2. Perancangan aplikasi sistem pakar untuk mendiagnosa penyakit menular seksual dengan metode Case Based Reasoning dilakukan dengan menggunakan aplikasi pemrograman berbasis desktop yaitu Visual Basic 2008 dan menggunakan database Microsoft Access 2007

\section{REFERENSI}

[1] Abidin, M, 2013, Perancangan Sistem Pakar Diagnose Infeksi Menular Seksual (IMS) berbasis WEB dengan Metode Forward dan Backward pada RSU DR.Sardjito Yogyakarta, Yogyakarta : STMIK AMIKOM.

[2] Dr. Mila Darmi. 2016. Hasil Wawancara / Obsevasi RSU Adam Malik Medan. (1-7).

[3] Faizal, E. (Mei 2012). Case Based Reasoning Diagnosis Penyakit Mata. Jurnal Teknologi Informasi dan Ilmu Komputer, 10(2), 29.

[4] Hendrayudi. 2010. Dasar - Dasar Pemrograman Visual Basic 2008. Bandung: Satu Nusa.

[5] Kusrini. 2009. Konsep dan Aplikasi Sistem Pendukung Keputusan. Yogyakarta : Penerbit Andi.

[6] Kusumadewi. Maret 2013. Sistem Pendukung Keputusan Menggunakan Metode Fuzzy Sugeno. Jurnal Universitas Sumatera Utara. Vol 1(2). Hal 3. Kamis 21 Juli 2016. 
[7] Listyorini, Tri. April 2014. Analisa Sistem Inference Fuzzy Sugeno Dalam Menentukan Haraga Penjualan Tanah Unruk Pembangunan Mini Market. Jurnal Simetris. Vol 5(1). Hal 90. Kamis 24 Maret2016.

[8] Mujilahwati, S. (September 2104). Diagnosa Penyakit Tanaman Hias Menggunakan Metode Certainty Factor Berbasis WEB. Jurnal Teknika, 6(2), 586.

[9] Rofiq, Muhammad. Februari 2013. Perancangan Manajemen Bandwidth Internet Menggunakan Metode Fuzzy Sugeno. Jurnal Ilmiah Teknologi dan Informasi ASIA. Vol 7(1). Hal 3. Kamis 24 Maret 2016.

[10] Suarna, N. 2008. Pedoman Panduan Praktikum Microsoft Office Access 2007. Bandung : Yrama Widya.

[11] Sulindawati, dan Muhammad Fathoni. Agustus 2010. Pengantar Analisa Perancangan Sistem. Jurnal Saintikom. Vol 9(2). Hal 14. Kamis 24 Maret 2016.

[12] Suwandi. Mei 2011. Aplikasi Sistem Inferensi Fuzzy Metode Sugeno Dalam Memperkirakan Produksi Air Mineral Dalam Kemasan. Jurnal Seminar Nasional Penelitian, Pendidikan dan Penerapan MIPA, Fakultas MIPA, Universitas Negeri Yogyakarta. Vol 1(1). Hal 2. Kamis 24 Maret 2016.

[13] Syahrizal, M. (Agustus 2012). Perancangan Sistem Aplikasi Pembuatan Roster Mata Kuliah Pada Perguruan Tinggi. Pelita Informatika Budi Dharma, 1,38.

[14] Toba, H., \& Tanadi, S. (Desember 2008). Pengembangan Case Based Reasoning pada Aplikasi Pemesanan Kain Berdasarkan Studi kasus Pada CV. Mitra KH Bandung. Jurnal informatika, 4(2), 135137. 